\title{
Major Asset Classes: A Brief Glossary ${ }^{1}$
}

\author{
Jarrett Tsai, Jorge Ruiz-Menjivar, and Martie Gillen²
}

\section{Introduction}

The best time to have started investing is yesterday. Whether you are saving for retirement, your child's college education, or a down payment on a house, it can only be in your benefit to choose and implement the proper investment plan. However, before you can make an informed decision on which financial vehicles to select for an investment portfolio or plan, you have to know about the available options and clearly understand the main idea and principles behind each of these investment vehicles. There are entire books written on these topics. This document aims to provide a brief but comprehensive glossary of the main financial investment vehicles.

\section{The Three Flavors of Investment Vehicles}

For the sake of simplicity, we will divide financial investment vehicles into three main types: stocks, bonds, and cash and cash equivalents. Descriptions of the main investment options for each category are offered below.

\section{Stocks}

Stocks are definitely the most discussed among our three flavors in printed and digital media. There are channels on television that cover them 24/7, articles published every day, and an abundance of information online. Stocks can be classified as common stocks or preferred stocks.
- Individual Stocks. An individual stock is simply a claim to partial ownership of a company. An easy way to understand this concept is to think of the company as one huge pizza, and each shareholder as an owner of one very tiny slice of that pizza.

- Mutual Funds. A mutual fund is a portfolio typically composed of multiple stocks from multiple companies and industries, which are actively managed (watched and hand-picked by a professional manager and bought and sold sometimes on a daily basis). Mutual funds are run by brokerage companies that charge a small percentagebased fee-usually about $0.75 \%$. A main benefit of investing in a mutual fund is diversification. The saying, "Don't put all your eggs in one basket," accurately reflects the mindset behind investing in mutual funds. Diversifying helps reduce investment risk. For example, if you own only one stock and it does poorly, your performance is also going to be poor. However, if you own ten stocks and three do poorly, but the remaining seven do well, then overall you will do well. Note that there are mutual funds that primarily invest in equity of stock funds. Examples include equity funds (e.g., small, mid, or large cap, income-oriented) and index funds. On the other hand, balanced funds invest in both stocks and bonds to reduce risk.

- ETFs (Exchange-Traded Funds). Exchange-traded funds are a bundle of stocks put together by a company to follow a broad stock index. The most common ETF is one that follows the Standard and Poor's 500 index (S\&P 500),

1. This document is FCS3352, one of a series of the Department of Family, Youth and Community Sciences, UF/IFAS Extension. Original publication date May 2019. Visit the EDIS website at https://edis.ifas.ufl.edu for the currently supported version of this publication.

2. Jarrett Tsai, undergraduate student, Finance Department, UF Warrington College of Business; Jorge Ruiz-Menjivar, assistant professor, Department of Family, Youth and Community Sciences; and Martie Gillen, associate professor, Department of Family, Youth and Community Sciences; UF/IFAS Extension, Gainesville, FL 32611.

The Institute of Food and Agricultural Sciences (IFAS) is an Equal Opportunity Institution authorized to provide research, educational information and other services

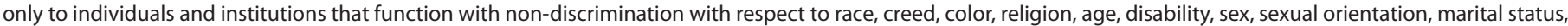

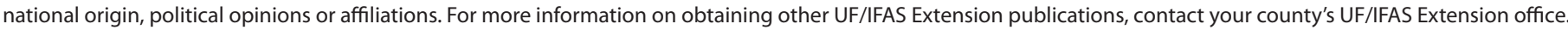
U.S. Department of Agriculture, UF/IFAS Extension Service, University of Florida, IFAS, Florida A \& M University Cooperative Extension Program, and Boards of County Commissioners Cooperating. Nick T. Place, dean for UF/IFAS Extension. 
which is the stock market index of the 500 largest companies in the US. The S\&P 500 is often used as a proxy or indicator for the overall well-being of the economy. The benefit of investing in an ETF is that you can track the market's movements and benefit from diversification, but pay low fees.

- Derivatives. A derivative simply means some investment vehicle (and its respective value) derived from or in relation to another asset (or assets) -in this case, primarily stocks. The most common derivative is an options contract. This is a contract that gives the right to the owner to either buy or sell a stock at a certain price and time. These contracts are mainly used as insurance as a way to speculate on the market. There are financial strategies that the average investor can employ to utilize derivatives, but the investor needs to have a strong understanding of the mechanics of this investment vehicle.

- Hedge Funds. Hedge funds are similar to mutual funds in the sense that someone pays a manager a fee in hopes that the returns will beat the overall market. They differ in that hedge funds employ complex and often highly risky strategies and are only available for accredited investors. One of the requirements to be an accredited investor is a net worth exceeding 1 million dollars.

\section{Bonds}

- Government Bonds. A bond can be thought of as an "I owe you" note. You buy the bond (lend the money) to the government, and at a later date, it pays you that money back in full. Sometimes, the bonds will also pay "coupons," meaning that you will receive a small interest payment on the money you have lent every six months until the bond matures. The biggest potential risk with bonds is that the borrower could default and not be able to pay back the money you lent. However, the government is perceived as riskless, because, in theory, it could continue to print money to repay any debt as needed.

- Corporate Bonds. Corporate bonds are bonds issued by corporations. They are perceived as riskier because a company has a much higher risk of going bankrupt and defaulting on debts than the US government does.

- Municipal Bonds. These investment vehicles are similar to corporate and government bonds, but they are issued by municipalities-local and state governments. The money used to pay these back is generated from the tax revenue of that specific municipality.

- Mutual Funds. Similar to mutual funds comprised of stocks, there are also mutual funds comprised of multiple bonds. As previously mentioned, mutual funds offer an opportunity to invest in a vehicle that benefits from diversification but does not require you to pay full face value for every bond within the funds. Fixed-income funds are an example of mutual funds that primarily invest in government bonds, corporate bonds, and other debt instruments.

\section{Cash and Cash Equivalents}

- Cash. Of the three flavors of investment vehicles, this is the most liquid. It is also the easiest and quickest option to access. Unless you need it to function on a regular basis, it is not recommended to hold much of your wealth in cash.

- Checking Accounts. These accounts are for daily expenses and usually do not pay interest. If they do pay interest, it is a negligible amount.

- Savings Accounts. These accounts are mostly for emergency money. They pay a slightly better interest rate than a checking account.

- Certificates of Deposit (CDs). CDs function in a way similar to bonds. You make a deposit at a bank, usually for $\$ 1,000$, for a specified amount of time, and you receive higher than average interest on your money. At the end of the specified time, the bank pays your money back in full plus any interest you have earned in the specified period of time. CDs are insured by the government and are perceived as riskless.

- Money Market Accounts. These accounts function like savings and checking accounts, but earn slightly better interest. Put simply, a financial institution (e.g., a bank) invests your money on your behalf in low-risk assets. These types of accounts are also insured by the government. Money market accounts have slightly higher minimum balance requirements than traditional savings or checking accounts and also have limited check-writing abilities.

\section{Reference}

Bodie, Z., Kane, A., \& Marcus, A. J. (2012). Essentials of Investments, 9th Edition. Boston, MA: McGraw-Hill/Irwin. 